The Canadian Mineralogist

Vol. 39, pp. 1053-1058 (2001)

\title{
KAMPFITE, A NEW BARIUM SILICATE CARBONATE MINERAL SPECIES FROM FRESNO COUNTY, CALIFORNIA
}

\author{
LAUREL C. BASCIANO AND LEE A. GROAT ${ }^{\S}$ \\ Department of Earth and Ocean Sciences, University of British Columbia, Vancouver, British Columbia V6T 1Z4, Canada
}

\author{
ANDREW C. ROBERTS
}

Geological Survey of Canada, 601 Booth Street, Ottawa, Ontario K1A OE8

JOEL D. GRICE

Research Division, Canadian Museum of Nature, P.O. Box 3443, Station D, Ottawa, Ontario K1P 6P4, Canada

GAIL E. DUNNING

773 Durshire Way, Sunnyvale, California 94087, U.S.A.

EUGENE E. FOORD ${ }^{\dagger}$

U.S. Geological Survey, Denver Federal Center, Denver, Colorado 80225, U.S.A.

INGRID M. KJARSGAARD

Geological Survey of Canada, 601 Booth Street, Ottawa, Ontario K1A OE8, Canada

ROBERT E. WALSTROM

P.O. Box 1728, Silver City, New Mexico 88062, U.S.A.

\begin{abstract}
Kampfite, ideally $\mathrm{Ba}_{6}\left[(\mathrm{Si}, \mathrm{Al}) \mathrm{O}_{2}\right]_{8}\left(\mathrm{CO}_{3}\right)_{2} \mathrm{Cl}_{2}\left(\mathrm{Cl}, \mathrm{H}_{2} \mathrm{O}\right)_{2}$, is a newly identified mineral species found in barium-silicate-rich deposits at Big Creek and Rush Creek, Fresno County, California. It forms irregular masses up to $10 \mathrm{~mm}$ in size enclosed in quartz-rich portions of the sanbornite-bearing rock. It is light blue-grey, with one perfect cleavage on $\{001\}$. Other physical properties are: brittle, translucent, nonfluorescent, vitreous luster, white streak, hardness 3, uneven fracture. Kampfite is uniaxial negative, $\omega$ 1.642(2), $\varepsilon$ 1.594(2), nonpleochroic. It is hexagonal, with unit-cell parameters refined from powder data: $a$ 5.244(2), $c$ 29.83(1) $\AA, V 710.5(4) \AA^{3}$, and $Z=1$. The strongest seven lines of the X-ray powder-diffraction pattern $[d$ in $\AA(I)(h k l)]$ are: 14.67(100)(002), 3.883(100)(104), 3.357(50)(106), 2.988(60)(0010), 2.887(50)(108), 2.616(70)(110), and 1.969(50)(1110). Precession photographs show that possible space-groups are $P 6_{3} / m m c, P \overline{6} 2 c, P 6_{3} m c, P \overline{3}_{1} c$ and $P 3_{1} c$. The empirical formula of kampfite (based on the average of three electron-microprobe analyses, normalized on 26 anions) is: $\left(\mathrm{Ba}_{5.83} \mathrm{Na}_{0.04} \mathrm{Ca}_{0.02}\right)_{\Sigma 5.89}$ $\left[\left(\mathrm{Si}_{5.18} \mathrm{Al}_{2.36}\right)_{\Sigma 7.54} \mathrm{O}_{15.08}\right]\left(\mathrm{CO}_{3}\right)_{2} \mathrm{Cl}_{2}\left[\left(\mathrm{H}_{2} \mathrm{O}\right) \mathrm{Cl}_{0.45}\right]_{\Sigma 1.45}$. The calculated density is $3.51 \mathrm{~g} / \mathrm{cm}^{3}$. All crystals studied contain inclusions or are multiple. Thus, it was not possible to unambiguously determine the correct space-group or precise details of the structure. However, the preliminary results show that the structure is based on double layers of tetrahedra, $\left[T_{4} \mathrm{O}_{8}\right]_{\infty}$, consisting of sixmembered rings, with three layers of Ba polyhedra connecting the layers of tetrahedra. Kampfite is part of the monteregianite-(Y) - wickenburgite series (Strunz classification) and is structurally and chemically similar to cymrite. The mineral name honors Anthony R. Kampf, Los Angeles County Museum of Natural History, for his many significant contributions to the study of new and rare minerals.
\end{abstract}

Keywords: kampfite, new mineral species, barium chloride silicate carbonate hydrate, X-ray data, electron-microprobe data, Big Creek, Rush Creek, Fresno County, California.

E-mail address: lgroat@eos.ubc.ca

Deceased. 


\section{SOMMAIRE}

La kampfite, dont la formule idéale serait $\mathrm{Ba}_{6}\left[(\mathrm{Si}, \mathrm{Al}) \mathrm{O}_{2}\right]_{8}\left(\mathrm{CO}_{3}\right)_{2} \mathrm{Cl}_{2}\left(\mathrm{Cl}, \mathrm{H}_{2} \mathrm{O}\right)_{2}$, est une espèce minérale récemment identifiée dans les indices enrichis en silicates de barium à Big Creek et Rush Creek, dans le comté de Fresno, en Californie. Elle forme des masses irrégulières atteignant $10 \mathrm{~mm}$ que renferment les parties riches en quartz d'une roche à sanbornite. Elle est bleu-gris pâle, avec un clivage parfait sur $\{001\}$. De plus, elle est cassante, translucide, non fluorescente, à éclat vitreux, à rayure blanche, ayant une dureté de 3 et une fracture inégale. La kampfite est uniaxe négative, $\omega$ 1.642(2), $\varepsilon$ 1.594(2), non pléochrö̈que. Elle est hexagonale, avec les paramètres réticulaires suivants affinés à partir d'un spectre de diffraction sur poudre: $a$ 5.244(2), $c$ 29.83(1) $\AA, V 710.5(4) \AA^{3}$, et $Z=1$. Les sept raies les plus intenses de ce spectre $[d$ en $\AA(I)(h k l)]$ sont: $14.67(100)(002), 3.883(100)(104)$, $3.357(50)(106), 2.988(60)(00 \overline{1})$ ), 2.887(50)(108), 2.616(70)(110), et 1.969(50)(11 $\overline{1} \overline{0})$. Les clichés de précession montrent que les groupes spatiaux suivants sont possibles: $P 6_{3} / m m c, P \overline{6} 2 c, P 6_{3} m c, P \overline{3}_{1} c$ et $P 3_{1} c$. La formule empirique de la kampfite (moyenne des résultats de trois analyses à la microsonde électronique, normalisés sur une base de 26 anions) est: $\left(\mathrm{Ba}_{5.83} \mathrm{Na}_{0.04} \mathrm{Ca}_{0.02}\right)_{\Sigma 5.89}$ $\left[\left(\mathrm{Si}_{5.18} \mathrm{Al}_{2.36}\right)_{\Sigma 7.54} \mathrm{O}_{15.08}\right]\left(\mathrm{CO}_{3}\right)_{2} \mathrm{Cl}_{2}\left[\left(\mathrm{H}_{2} \mathrm{O}\right) \mathrm{Cl}_{0.45}\right]_{\Sigma 1.45}$. La densité calculée est égale à $3.51 \mathrm{~g} / \mathrm{cm}^{3}$. Tous les cristaux étudiés contiennent des inclusions ou sont multiples. Ainsi, il ne nous a pas été possible d'établir le groupe spatial sans ambiguïté ou les détails précis de la structure. Toutefois, les résultats obtenus montrent que la structure est faite de couches doubles de tétraèdres, $\left[T_{4} \mathrm{O}_{8}\right]_{\infty}$, contenant des anneaux à six membres, avec trois niveaux de polyèdres à barium assurant la connexion entre les couches de tétraèdres. La kampfite fait partie de la série montérégianite-(Y) - wickenburgite (classification de Strunz), et elle est semblable à la cymrite tant du point de vue structural que chimique. Le nom honore Anthony R. Kampf, du Los Angeles County Museum of Natural History, et reconnait ainsi ses contributions importantes à l'étude des minéraux rares et de nouvelles espèces.

(Traduit par la Rédaction)

Mots-clés: kampfite, nouvelle espèce minérale, silicate carbonaté chloruré hydraté de barium, données de diffraction X, données de microsonde électronique, Big Creek, Rush Creek, comté de Fresno, Californie.

\section{INTRODUCTION}

Kampfite was discovered by one of us (REW) in 1964 at the Esquire \#1 claim, Rush Creek, eastern Fresno County, California ( $\mathrm{NE}^{1 / 4} \mathrm{NW}^{1 / 4}$ Section 16 , T11S, R25E, Mount Diablo Meridian, lat. $37^{\circ} 05^{\prime} \mathrm{N}$, long. $119^{\circ} 16^{\prime} 20^{\prime \prime} \mathrm{W}$ ). The mineral occurs as irregular masses up to $1 \mathrm{~cm}$ across enclosed in a steeply dipping quartz-sanbornite outcrop exposed for $3 \mathrm{~m}^{2}$ along a steep hill overlooking Rush Creek. Associated minerals at the type locality include celsian, fresnoite, macdonaldite, pyrrhotite, titantaramellite, traskite, witherite, and two new minerals, UKBC-10, a Ba-Fe-Al$\mathrm{Cl}$ silicate related to cerchiaraite (Basso et al. 2000) and UKRC-21, a hydrated form of $\mathrm{SiO}_{2}$. Small inclusions of celsian, witherite and UKBC-10 have been identified within kampfite. Rare grains of kampfite have been identified at the Esquire \#7 claim along Big Creek, Fresno County, California (SE1/4 SE1/4 Section 27, T11S, R25E, Mount Diablo Meridian, lat. 36 56 40" N, long. $\left.119^{\circ} 14^{\prime} 28^{\prime \prime} \mathrm{W}\right)$. The Big Creek site is the type locality for alforsite, bigcreekite and walstromite, and is known for a number of rare Ba-bearing minerals including anandite, bazirite, benitoite, celsian, gillespite, fresnoite, macdonaldite, muirite, pellyite, titantaramellite and verplanckite (Alfors et al. 1965, Alfors \& Pabst 1984, Basciano et al. 2001). Additional minerals currently under study from the Big Creek locality include UKBC10, UKBC-27, a Ba-Fe-Ca-Mn silicate-phosphate, and minerals UKBC-39a and 39b, the $\mathrm{Fe}-\mathrm{Cl}$ analogues of ericssonite and orthoericssonite, respectively. Our eventual aim is to completely characterize the mineral- ogy of the Rush Creek and Big Creek occurrences and to draw conclusions regarding the paragenesis of $\mathrm{Ba}-$ bearing minerals.

The Big Creek and Rush Creek deposits consist of gneissic rocks composed of variable amounts of sanbornite and quartz with minor amounts of diopside, pyrrhotite and various Ba-bearing minerals. The rocks form conformable tabular bodies up to $13 \mathrm{~m}$ thick within foliated quartzite at or within $100 \mathrm{~m}$ of the contact with a granodiorite pluton (Alfors et al. 1965). They probably began as sediments of Paleozoic age that were metamorphosed prior to being uplifted to their present position. The mineral assemblages within the rocks are most likely related to the initial bulk chemical composition of the sediments prior to metamorphism. Hinthorne (1974) suggested that sanbornite was formed by the reaction of witherite with quartz, and that the sanbornitequartz rocks formed at temperatures between 440 and $600^{\circ} \mathrm{C}$. On the basis of textures observed in thin section, we believe that kampfite formed prior to both sanbornite and quartz, but the lack of $\mathrm{Fe}$ in the chemical formula suggests that it formed later than titantaramellite, traskite and UKBC-10.

Kampfite is named after Anthony Robert Kampf (b. 1948), Curator and Section Head of Minerals, Los Angeles County Museum of Natural History, for his many significant contributions to the crystallographic study of new and rare minerals. The mineral and mineral name have been approved by the Commission on New Minerals and Mineral Names, IMA. Cotype material is housed in the M.Y. Williams Museum at the University of British Columbia, Vancouver, British Columbia, and 
in the Systematic Reference Series of the National Mineral Collection of Canada, Geological Survey of Canada, Ottawa, Ontario (NMCC 68090).

\section{Physical and Optical Properties}

Kampfite is light blue-grey and has a well-developed cleavage on $\{001\}$ (Fig. 1). The cleavable masses are brittle, translucent, nonfluorescent and have a vitreous luster, uneven fracture and a white streak. Kampfite has an approximate Mohs hardness of 3 and a calculated density (on the basis of the empirical formula and cell dimensions derived from the X-ray powder-diffraction study) of $3.51 \mathrm{~g} / \mathrm{cm}^{3}$. The density of kampfite could not be measured directly owing to the presence of numerous inclusions of UKBC-10, celsian and witherite.
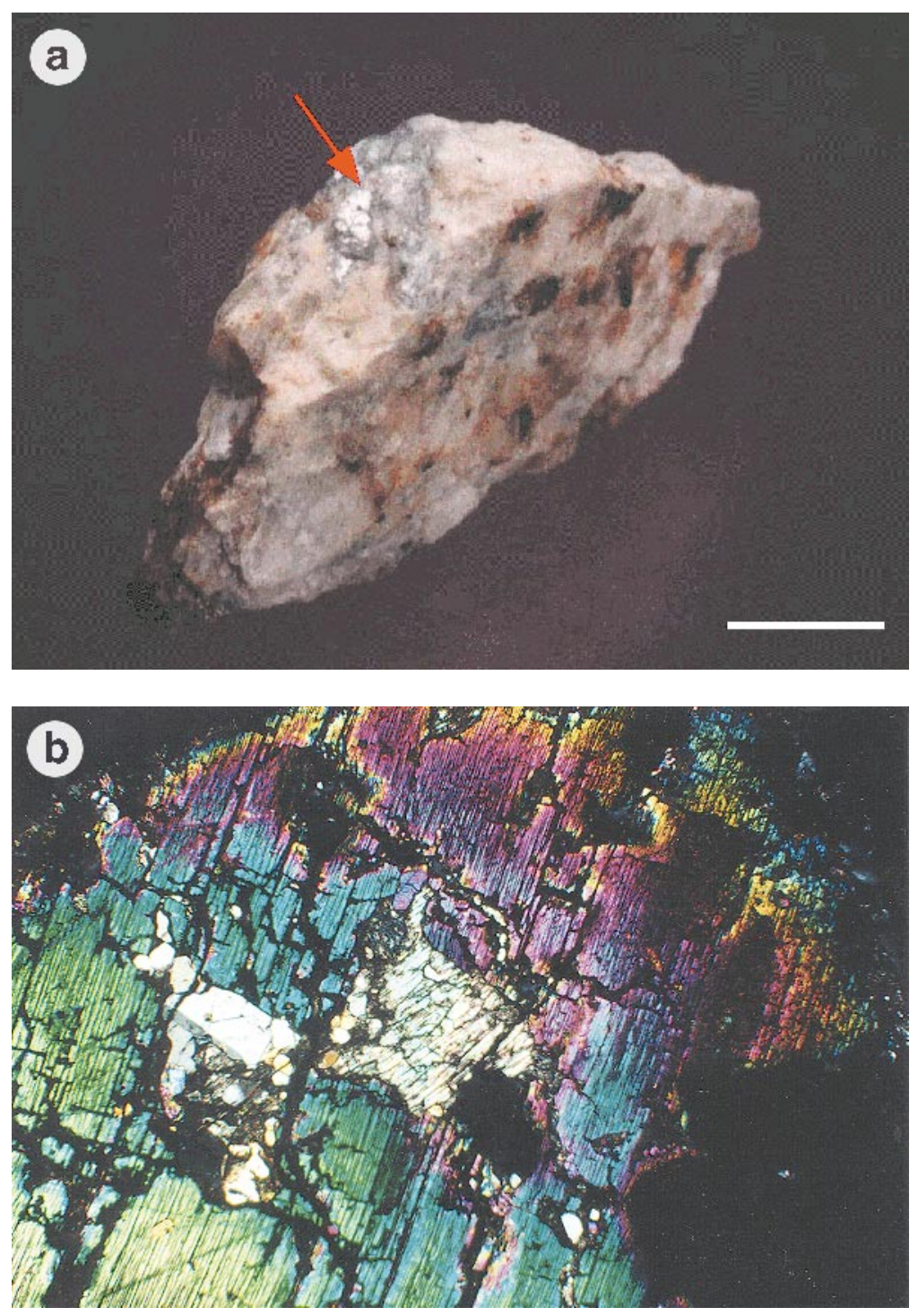

FIG. 1. (a) A mass of kampfite in quartz-sanbornite-bearing rock. The scale bar is $1 \mathrm{~cm}$ in length. (b) Photomicrograph of kampfite (center of field, third-order interference colors). The large surrounding grain with second-order interference colors is sanbornite; the grain to the left with first-order white-grey interference colors is celsian. Polarized light; the field of view is $5.1 \mathrm{~mm}$. 
Kampfite is uniaxial negative, with indices of refraction $\omega 1.642 \pm 0.002$ and $\varepsilon 1.594 \pm 0.002$ (measured at $589 \mathrm{~nm})$. The mineral is nonpleochroic, and extinction is parallel to the $\{001\}$ cleavage. One grain is biaxial negative with $2 V_{\text {meas }}$ of $20(5)^{\circ}$ and indices of refraction $\alpha 1.641 \pm 0.001, \beta 1.642 \pm 0.001, \gamma_{\text {calc }} 1.642$, slight dispersion, $r<v$; at present we regard this as anomalous and not representative of the mineral. Application of the Gladstone-Dale relationship (Mandarino 1981) gives a compatibility index of -0.059 , which is considered to be fair.

\section{Chemical Composition}

Chemical analyses were performed on a JEOL 733 electron microprobe with Tracor Northern 5500 and 5600 automation, operated in the wavelength-dispersion mode with the following conditions: excitation voltage $15 \mathrm{kV}$, beam current $20 \mathrm{nA}$ and beam diameter $30 \mu \mathrm{m}$. Data on standards were collected for $50 \mathrm{~s}$ or to $0.25 \%$ precision $(4 \sigma$ level), whichever was attained first; data on kampfite were collected for $25 \mathrm{~s}$ or to $0.5 \%$ precision, whichever was attained first. An element was considered to be observed only if it is significant at the $4 \sigma$ (measured) level. The following standards were used: albite $(\mathrm{Na} K \alpha)$, almandine $(\mathrm{Al} K \alpha)$, sanbornite $(\mathrm{Si} K \alpha$, $\mathrm{Ba} L \alpha)$, marialite $(\mathrm{Cl} K \alpha)$, and diopside $(\mathrm{Ca} K \alpha) . \mathrm{F}, \mathrm{Mg}$, $\mathrm{Sc}, \mathrm{Mn}, \mathrm{Fe}$, and $\mathrm{Sr}$ were sought but not detected. Data reduction was performed with a PAP routine in XMAQNT (pers. commun., C. Davidson, CSIRO). The results of the electron-microprobe study are given in Table 1. On the basis of 26 anions (derived from the crystal-structure study), the empirical formula $\left(\mathrm{Ba}_{5.83}\right.$ $\left.\mathrm{Na}_{0.04} \mathrm{Ca}_{0.02}\right)_{\Sigma 5.89}\left[\left(\mathrm{Si}_{5.18} \mathrm{Al}_{2.36}\right)_{\Sigma 7.54} \mathrm{O}_{15.08}\right]\left(\mathrm{CO}_{3}\right)_{2} \mathrm{Cl}_{2}$ $\left[\left(\mathrm{H}_{2} \mathrm{O}\right) \mathrm{Cl}_{0.45}\right]_{\Sigma 1.45}$ was calculated from an average of three analyses. The ideal formula for kampfite is $\mathrm{Ba}_{6}\left[(\mathrm{Si}, \mathrm{Al}) \mathrm{O}_{2}\right]_{8}\left(\mathrm{CO}_{3}\right)_{2} \mathrm{Cl}_{2}\left(\mathrm{Cl}, \mathrm{H}_{2} \mathrm{O}\right)_{2}$.

The presence of $\mathrm{H}_{2} \mathrm{O}$ and $\mathrm{CO}_{2}$ was confirmed by micro-infrared-absorption spectroscopy. The infraredabsorption spectrum of kampfite, shown in Figure 2, was obtained using a Bomem Michelson MB-120

TABLE 1. CHEMICAL COMPOSITION OF KAMPFITE

\begin{tabular}{lrrlrr}
\hline & Average & Ideal** & & Average & Ideal $^{* *}$ \\
$\mathrm{SiO}_{2}$ & 20.14 & 20.47 & $\mathrm{~S}^{4+}$ & 5.18 & 5.33 \\
$\mathrm{Al}_{2} \mathrm{O}_{3}$ & 7.76 & 8.70 & $\mathrm{Al}^{3+}$ & 2.36 & 2.67 \\
$\mathrm{CO}_{2}{ }^{*}$ & 5.69 & 5.63 & $\mathrm{C}^{4+}$ & 2.00 & 2.00 \\
$\mathrm{BaO}$ & 57.72 & 58.79 & $\mathrm{Ba}^{2+}$ & 5.83 & 6.00 \\
$\mathrm{CaO}$ & 0.06 & 0.00 & $\mathrm{Ca}^{2+}$ & 0.02 & 0.00 \\
$\mathrm{Na}$ & 0.08 & 0.00 & $\mathrm{Na}^{*}$ & 0.04 & 0.00 \\
$\mathrm{Cl}$ & 5.60 & 6.80 & $\mathrm{Cl}^{+}$ & 2.45 & 3.00 \\
$\mathrm{H}_{2} \mathrm{O}^{+}$ & 1.16 & 1.15 & $\mathrm{H}^{+}$ & 2.00 & 2.00 \\
O=Cl & -1.26 & -1.53 & $\mathrm{O}^{2-}$ & 23.56 & 24.17 \\
TOTAL & 96.95 & 100.00 & & &
\end{tabular}

Note: Average is of three analyses. Analyses are normalized on 26 anions assuming two $\mathrm{C}$ atoms per formula unit. ${ }^{\star}$ Determined by stoichiometry. ${ }^{\star \star}$ Calculated for $\mathrm{Si} \cdot \mathrm{Al}=2: 1$ three $\mathrm{Cl}$ and one $\mathrm{H}_{2} \mathrm{O}$ per formula unit based on crystal-structure study.
Fourier-transform spectrometer with a diamond-anvil cell microsampling device. The spectrum shows a small sharp peak at $1648 \mathrm{~cm}^{-1}$ due to $\mathrm{H}-\mathrm{O}-\mathrm{H}$ bending and a broad shallow peak centered at $3421 \mathrm{~cm}^{-1}$ due to $\mathrm{O}-\mathrm{H}$ stretching, thus confirming the presence of $\mathrm{H}_{2} \mathrm{O}$ molecules in the structure. In addition, the spectrum shows very large sharp peaks at 982 and $1436 \mathrm{~cm}^{-1}$ and a small sharp peak at $1758 \mathrm{~cm}^{-1}$, confirming the presence of $\mathrm{CO}_{3}$ groups in the structure.

\section{X-RAy CRystallography}

Precession single-crystal photographs showed that kampfite is hexagonal, with approximate unit-cell dimensions a 5.25, $c 29.8 \AA$. Possible space groups are $P 6_{3} / m m c, P \overline{6} 2 c, P 6_{3} m c, P \overline{3}_{1} c$ and $P 3_{1} c$. Unit-cell parameters refined using $X$-ray powder-diffraction data (Table 2) are $a$ 5.244(2), $c$ 29.83(1) $\mathrm{A}, V 710.5(4) \AA^{3}, c /$ $a$ 5.6884. A significant amount of time was spent locating an inclusion-free crystal for structure determination. A full sphere of intensity data was collected using a Siemens $P 4 / C C D$ diffractometer at the University of Manitoba. The structure was solved and refined in each of the space groups indicated by the precession singlecrystal photographs. The best results were obtained for space group $\mathrm{P}_{3} m c$. However, the bond lengths in this case depart rather seriously from expected values and lack internal coherency. Careful inspection of the crystal under a polarizing microscope showed that it is likely

TABLE 2. X-RAY POWDER-DIFFRACTION DATA FOR KAMPFITE

\begin{tabular}{|c|c|c|c|c|c|c|c|}
\hline lest $_{\text {est }}$ & $d_{\text {meas }}$ & $d_{\text {calc }}$ & $n k l$ & $l_{\text {est }}$ & $d_{\text {meas }}$ & $d_{c a l c}$ & $n k t$ \\
\hline 100 & 14.67 & 14.917 & 002 & $* 10$ & 1.864 & 1.865 & 0016 \\
\hline 20 & 7,468 & 7.459 & 004 & 5 & 1.806 & 1.807 & 2010 \\
\hline \multirow[t]{2}{*}{20} & 4.535 & 4.541 & 100 & 5 & 1.725 & 1.725 & 1016 \\
\hline & & 4.490 & 101 & 3 & 1.713 & 1.716 & 210 \\
\hline 30 & 4.343 & 4.345 & 102 & & & 1.714 & 211 \\
\hline 15 & 4.123 & 4.131 & 103 & +20 & 1.672 & 1.673 & 214 \\
\hline$* 100$ & 3.883 & 3.879 & 104 & 1 & 1.653 & 1.650 & 215 \\
\hline 5 & 3.731 & 3.729 & 008 & $* 10$ & 1.621 & 1.622 & 216 \\
\hline *15 & 3.619 & 3.614 & 105 & 1 & 1.593 & 1.592 & 217 \\
\hline${ }^{*} 50$ & 3.357 & 3.353 & 106 & & & 1.559 & 218 \\
\hline$* 15$ & 3.113 & 3.108 & 107 & 40 & 1.557 & 1.557 & $10 \underline{18}$ \\
\hline${ }^{*} 60$ & 2.988 & 2.983 & $00 \underline{10}$ & & & 1.554 & $20 \underline{14}$ \\
\hline *50 & 2.887 & 2.882 & $1 \overrightarrow{08}$ & *15 & 1.516 & 1.514 & $3 \overline{00}$ \\
\hline 5 & 2.675 & 2.677 & 109 & 10 & 1.489 & 1.492 & $00 \underline{20}$ \\
\hline${ }^{*} 70$ & 2.616 & 2.622 & 110 & & & 1.489 & $21 \underline{10}$ \\
\hline 5 & 2.582 & 2.582 & 112 & 1 & 1.444 & 1.450 & 2111 \\
\hline \multirow[t]{2}{*}{40} & 2.495 & 2.494 & $10 \underline{10}$ & & & 1.441 & $20 \underline{16}$ \\
\hline & & 2.486 & 0012 & 3 & 1.415 & 1.417 & 1020 \\
\hline 5 & 2.330 & 2.329 & $10 \underline{11}$ & 15 & 1.402 & 1.413 & $21 \underline{12}$ \\
\hline$* 20$ & 2.272 & 2.271 & $2 \overline{200}$ & & & 1.403 & 308 \\
\hline 1 & 2.242 & 2.245 & 202 & & & $1.40 \uparrow$ & $11 \underline{18}$ \\
\hline 1 & 2.216 & 2.214 & 203 & 1 & 1.372 & 1.374 & $21 \underline{13}$ \\
\hline$* 40$ & 2.176 & 2.172 & 204 & +10 & 1.350 & 1.350 & 3010 \\
\hline$* 30$ & 2.144 & 2.145 & 118 & 15 & 1.337 & 1.339 & 2018 \\
\hline$\star 20$ & 2.063 & 2.065 & 206 & & & 1.337 & 2114 \\
\hline 1 & 2.005 & 2.004 & 207 & ${ }^{*} 10$ & 1.311 & 1.311 & 220 \\
\hline$\star 50$ & 1.969 & 1.969 & $11 \underline{10}$ & *15 & 1.296 & 1.297 & $11 \underline{20}$ \\
\hline$\star 30$ & 1.930 & 1.929 & $10 \overline{14}$ & & & & \\
\hline
\end{tabular}

Note: Data collected using a $114.6 \mathrm{~mm}$ Debye-Scherrer powder camera, $\mathrm{Cu}$ radiation. Ni filter $\left(\lambda, C_{0} K_{\mathrm{C}}=1.54178 \mathrm{~A}\right.$ ), visually estimated intensities; not corrected for shrinkage and no internal standard indexed with a 5.244, c $29.83 \mathrm{~A}$. *Reflections used for unit-cell refinement. 


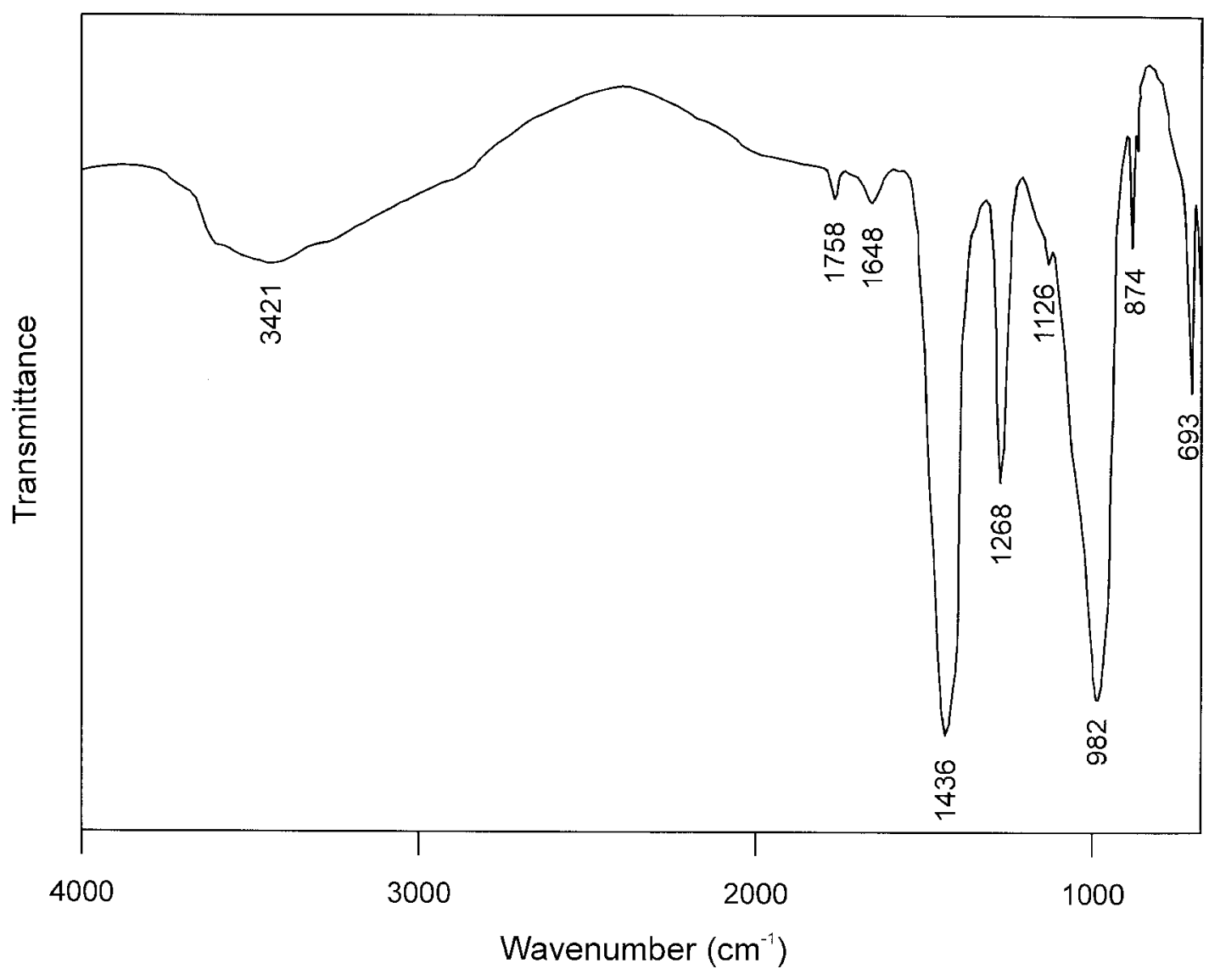

FIG. 2. Infrared-absorption spectrum of kampfite.

composed of two non-twinned individuals, and this is the most probable reason for the poor quality of the data. Although it was not possible to determine the correct space-group or precise details of the crystal structure, the results of the crystal-structure study show that kampfite is a sheet silicate. The main structural feature is the unbranched single layer $\left\{\boldsymbol{u} \boldsymbol{B}, 1_{\infty}^{2}\right\}\left[T_{2} \mathrm{O}_{5}\right]$ (Liebau 1985) of six-membered rings, which is typical for the mica group of minerals. In kampfite, however, pairs of polar sheets are joined via apical $\mathrm{O}$ atoms to form unbranched zweier double layers $\left\{\boldsymbol{u B}, 2^{2}{ }_{\infty}\right\}\left[T_{4} \mathrm{O}_{8}\right]$ (Liebau $1985)$ oriented parallel to (001). The layers of $\mathrm{SiO}_{4}$ tetrahedra are connected by three layers of Ba polyhedra. Edge-sharing $\mathrm{Ba}(2)$ polyhedra form sheets that are bonded by $\mathrm{O}(2)$ atoms to the tetrahedra pointing along [001]. Edge-sharing $\mathrm{Ba}(3)$ polyhedra form sheets that are bonded by $\mathrm{O}(1)$ atoms to the tetrahedra pointing along [00 $\overline{1}]$, and $\mathrm{Ba}(1)$ polyhedra are located between the sheets of $\mathrm{Ba}(2)$ and $\mathrm{Ba}(3)$ polyhedra. Sheets of $\mathrm{Ba}(2)$ and $\mathrm{Ba}(3)$ polyhedra are bonded by $\mathrm{Cl}(1)$ atoms along
[001] with $\mathrm{Ba}(1)$ atoms occupying the spaces between them. The $\mathrm{H}_{2} \mathrm{O}$ molecules are located in spaces between $\mathrm{Ba}(2)$ polyhedra and $\mathrm{Ba}(3)$ polyhedra. The layering of $\mathrm{SiO}_{4}$ tetrahedra and $\mathrm{Ba}$ polyhedra is responsible for the perfect $\{001\}$ cleavage of kampfite.

\section{DiscusSiON}

The only other known barium silicate carbonate mineral is fencooperite, $\mathrm{Ba}_{6} \mathrm{Fe}^{3+}{ }_{3} \mathrm{Si}_{8} \mathrm{O}_{23}\left(\mathrm{CO}_{3}\right)_{2} \mathrm{Cl}_{3} \cdot \mathrm{H}_{2} \mathrm{O}$ (Roberts et al. 2001). The crystal structure of fencooperite also contains layers of $\mathrm{SiO}_{4}$ tetrahedra, but these do not form continuous double sheets as in kampfite; instead, they form $\mathrm{Si}_{8} \mathrm{O}_{22}$ islands of double open-branched triple-branched tetrahedra (Grice 2001).

Kampfite belongs to Dana class 78.1 (unclassified silicates) and is part of VIII/H.38, the monteregianite(Y) - wickenburgite series [phyllosilicates (layered) mica minerals with double layers of tetrahedra and related structures] in the Strunz system of classification. 
The unbranched zweier double layers in kampfite have also been described for high-temperature phases of feldspar composition: $\mathrm{Ca}\left[\mathrm{AlSiO}_{4}\right]_{2}$ (hT) (Takéuchi \& Donnay 1959), $\mathrm{Sr}\left[\mathrm{AlSiO}_{4}\right]_{2}(\mathrm{hT})$ and $\mathrm{Pb}\left[\mathrm{AlSiO}_{4}\right]_{2}$ (hT) (Pentinghaus 1975), $\mathrm{Ba}\left[\mathrm{AlSiO}_{4}\right]_{2}$ (hT) (Takéuchi 1958) and $\mathrm{Rb}\left[\mathrm{AlSi}_{3} \mathrm{O}_{8}\right]$ (hT) (Sorrel \& Negas 1963). They have also been described for the minerals cymrite, $\mathrm{Ba}\left[\mathrm{AlSiO}_{4}\right]_{2} \bullet \mathrm{H}_{2} \mathrm{O}$ (Drits et al. 1975, Bolotina et al. 1991), vertumnite, $\mathrm{Ca}_{8} \mathrm{Al}_{4}\left(\mathrm{Al}_{4} \mathrm{Si}_{5}\right) \mathrm{O}_{12}(\mathrm{OH})_{36} \cdot 10 \mathrm{H}_{2} \mathrm{O}$ (Galli \& Passaglia 1978) and strätlingite, $\mathrm{Ca}_{8} \mathrm{Al}_{4}\left(\mathrm{Al}_{4} \mathrm{Si}_{4}\right) \mathrm{O}_{8}(\mathrm{OH})_{40} \bullet 10 \mathrm{H}_{2} \mathrm{O}$ (Rinaldi et al. 1990).

\section{ACKNOWLEDGEMENTS}

The authors thank E.A. Moffatt (Canadian Conservation Institute, Ottawa) for the infrared-absorption study. The manuscript was improved by comments from an anonymous reviewer, J.M. Jackson, J.M. Hughes, J.A. Mandarino and R.F. Martin. Financial support was provided by the Natural Sciences and Engineering Research Council of Canada in the form of a Research Grant to LAG, and by equipment grants from the BC Science and Technology Development Fund and the University of British Columbia.

\section{REFERENCES}

Alfors, J.T. \& PABST, A. (1984): Titanian taramellites in western North America. Am. Mineral. 69, 358-373.

Stinson, M.C., Matthews, R. A. \& Pabst, A. (1965): Seven new barium minerals from eastern Fresno County, California. Am. Mineral. 50, 314-340.

Basciano, L.C., Groat, L.A., Roberts, A.C., Gault, R.A., DunNing, G.E. \& WALSTROM, R.E. (2001): Bigcreekite: a new barium silicate mineral species from Fresno County, California. Can. Mineral. 39, 761-768.

Basso, R., Lucchetti, G., Zefiro, L. \& PAlenzonA, A. (2000): Cerchiaraite, a new natural $\mathrm{Ba}-\mathrm{Mn}-$ mixed-anion silicate chloride from the Cerchiara mine, northern Apennines, Italy. Neues Jahrb. Mineral., Monatsh., 373-384.

Bolotina, N.B., Rastsvetaeva, R.K., Andrianov, V.I. \& KASHAEV, A.A. (1991): Refinement of modulated crystals: structure of cymrite. Sov. Phys. Crystallogr. 36, 190-194.
Drits, V.A., Kashaev, A.A. \& Sokolova, G.V. (1975): Crystal structure of cymrite. Sov. Phys. Crystallogr. 20, 171175 .

Galli, E. \& Passaglia, E. (1978): Vertumnite: its crystal structure and relationship with natural and synthetic phases. Tschermaks Mineral. Petrogr. Mitt. 25, 33-46.

GRICE, J.D. (2001): The crystal structure of fencooperite: unique $\left[\mathrm{Fe}^{3+}{ }_{3} \mathrm{O}_{13}\right]$ pinwheels cross-connected by $\left[\mathrm{Si}_{8} \mathrm{O}_{22}\right]$ islands. Can. Mineral. 39, 1065-1072.

HinTHORNE, J.R. (1974): The Origin of Sanbornite and Related Minerals. Ph.D. thesis, Univ. California, Santa Barbara, California.

LiEBAU, F. (1985): Structural Chemistry of Silicates: Structure, Bonding, and Classification. Springer-Verlag, New York, N.Y.

MAndarino, J.A. (1981): The Gladstone-Dale relationship. IV. The compatibility concept and its application. Can. Mineral. 19, 441-450.

Pentinghaus, H. (1975): Hexacelsiane. Fortschr. Mineral. 53, $1-65$.

Rinaldi, R., Sacerdoti, M. \& Passaglia, E. (1990): Strätlingite: crystal structure, chemistry, and a reexamination of its polytype vertumnite. Eur. J. Mineral. 2, 841-849.

Roberts, A.C., Grice, J.D., Dunning, G.E. \& Venance, K.E. (2001): Fencooperite, $\mathrm{BaFe}^{3+}{ }_{3} \mathrm{Si}_{8} \mathrm{O}_{23}\left(\mathrm{CO}_{3}\right)_{2} \mathrm{Cl}_{3} \bullet \mathrm{H}_{2} \mathrm{O}$, a new mineral species from Trumbull Peak, Mariposa County, California. Can. Mineral. 39, 1059-1064.

Sorrel, C.A. \& NegAs, T. (1963): Metastable rubidium aluminium silicate with a hexagonal sheet structure. Science $141,917$.

TAKÉUCHI, Y. (1958): A detailed investigation of the structure of hexagonal $\mathrm{BaAl}_{2} \mathrm{Si}_{2} \mathrm{O}_{8}$ with reference to its $\alpha-\beta$ inversion. Mineral. J. 2, 311-332.

\& DonnAY, G. (1959): The crystal structure of hexagonal $\mathrm{CaAl}_{2} \mathrm{Si}_{2} \mathrm{O}_{8}$. Acta Crystallogr. 12, 465-470.

Received September 16, 2000, revised manuscript accepted June 29, 2001 